Document downloaded from:

http://hdl.handle.net/10251/48284

This paper must be cited as:

Cabrera Marcet, E.; Pardo Picazo, MA.; Cabrera Rochera, E.; Arregui De La Cruz, F. (2012). Tap water costs and service sustainability, a close relationship. Water Resources Management. 27(1):239-253. doi:10.1007/s11269-012-0181-3.

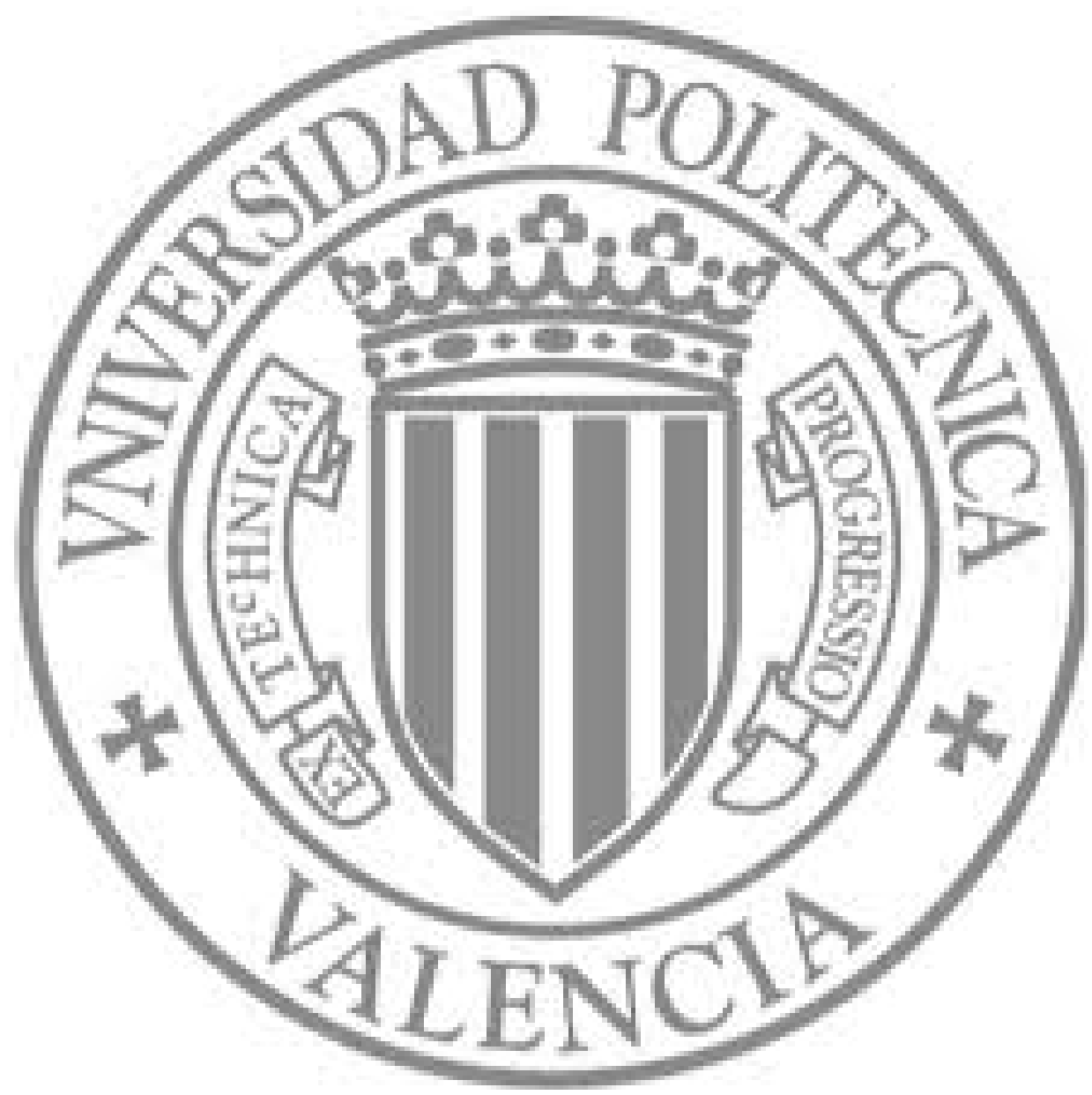

The final publication is available at

http://dx.doi.org/10.1007/s11269-012-0181-3

Copyright Springer Verlag (Germany) 


\title{
TAP WATER COSTS AND SERVICE SUSTAINABILITY, A CLOSE RELATIONSHIP
}

Cabrera E ${ }^{1}$., Pardo, M.A. ${ }^{2}$, Cabrera E. Jr. ${ }^{3}$ and Arregui F.J. ${ }^{4}$

${ }^{1}$ Professor, ITA, Dept. Hydraulic and Environmental Engineering, Univ. Politécnica de Valencia, C/Camino de Vera s/n. 46022, Valencia, Spain. Email: ecabrera@ita.upv.es

${ }^{2}$ Assistant Professor, INGHA, Area of hydraulic engineering, school of engineering, Univ. of Alicante, San Vicente del Raspeig, PO BOX 99, 03080, Alicante, Spain. Email: mpardo@ua.es

${ }^{3}$ Associate Professor, ITA, Dept. Hydraulic and Environmental Engineering, Univ. Politécnica de Valencia, C/Camino de Vera s/n. 46022, Valencia, Spain. Email: qcabrera @ita.upv.es

${ }^{4}$ Associate Professor, ITA, Dept. Hydraulic and Environmental Engineering, Univ. Politécnica de Valencia, C/Camino de Vera s/n. 46022, Valencia, Spain. Email: farregui @ita.upv.es

\begin{abstract}
Water is currently an essential and strategic resource for society and its importance will rise in the future due to the increasing number of threats. However, water management is not currently up to par taking into consideration this well acknowledged importance. Generally speaking, water use is not efficient and loss figures are often too high. The reasons behind this situation are complex and diverse, however, in principle, they can be divided into four categories: cultural, political, social and economic. Since the latter are of most importance, this paper focuses on water costs from source to tap.
\end{abstract}

The economic analysis presented quantifies the costs of a sustainable urban water service in a structured way. The second part of the paper present a case study in which the economic losses linked to leakage are assessed as a function of how expenses are recovered. The cost of apparent 
losses could also be assessed in a similar way and will always be higher, since apparent losses (unlike real ones) are present throughout the whole water cycle, thus increasing the unit costs.

\section{INTRODUCTION}

Society is becoming increasingly aware of environmental issues. This interest, however, still needs to be reflected in a significant improvement in the management of water services. The deficiencies in this management are evidenced by the great variability in per capita consumption and unit price in similar countries (OFWAT, 2009; OECD, 2010; BDEW, 2010). According to IWA's latest statistics on the sector (including some of the largest cities on the planet) the price paid by users for an annual consumption of $200 \mathrm{~m}^{3}$ shows a dispersion that is difficult to explain. The most expensive city is Copenhagen, where such a volume costs $765 \mathrm{US} \$$. The cheapest is Milan, where the same amount only costs 33US\$ (IWA, 2010), a difference that the climatic and socio-economic context of both cities does not justify. Without considering historic and cultural reasons it is difficult to explain the fact that the price paid in Milan is not even $5 \%$ of Copenhagen's. This is hardly a surprise considering that significant differences can even be found within one particular country (Kanakoudis and Tsitsifli, 2009).

It seems clear that the pricing structures and the concepts included in the water bill of each city are different. Copenhagen probably considers all kinds of costs, including environmental costs. Similarly, Milan's prices are likely to be subsidized and the citizens pay for them both directly (though tariffs) and indirectly (through taxes), which is hardly a best practice. On the one hand, subsidizing big water consumers does not encourage efficiency. On the other hand, network efficiency (leakage) is strongly linked to the price of water; the cheaper the cubic meter is, the smaller the incentive to invest in network maintenance to avoid the losses.

The final price of water depends on the costs included in the final bill. The Water Framework Directive (WFD) warns that recovery should be undertaken "including environmental and 
resource costs" (EU, 2000). For this reason, this paper will identify such costs (regardless of whether or not they are not included in the final price) and then separate them into fixed and variable, according to their dependence on water production. This discrimination is necessary to estimate the cost of leakage linked to the variable component (Kanakoudis et al., 2011).

A final distinction should be made between cost recovery and tariffs. For economic sustainability to be achieved revenues and expenditures are required to be balanced, regardless of how the total revenue is obtained from the consumers. Tariffs are the mechanism enabling those costs to be distributed among the different consumer types in accordance with political criteria. Conceptually, there is a parallelism between the tariff system and the fiscal policy in a country; the budget needs to be met with revenues from taxes, and yet the way to distribute those taxes can be of a very different nature depending on each country. In a similar line, access to water must be fully compatible with the cost recovery principle. Again, an adequate tariff system should and can make such principle compatible with the universal right to water.

Although water economy can be studied from a broader perspective, considering the river basin scale (Zhu and van Ierland, 2012) or an integral water resource management context in which the economics of reused water should be considered (Molinos-Senante et al., 2012), this paper focuses on urban water; proposing a cost structure that will allow for an understanding of why the price of tap water is so different around the world, and eventually, how to calculate the real value of water lost through leaks in a network.

\section{WATER COSTS}

Before recovering water costs, it is necessary to identify and classify them independently of the use of water (urban, agricultural or industrial). Some authors (Roth, 2001) group such costs in seven concepts, while others (Rogers et al., 1999) divided them into 5 groups: 
Resource costs. A key concept for the WFD integrated by three terms:

Purchase of bulk water (treated or untreated) from another operator.

Temporal opportunity cost. Associated to the lack of revenue (e.g. lost crops due to a lack of irrigation). Generally speaking, the owner of the water rights sells them to satisfy more important uses (urban) or to obtain higher profitability. This term can play a relevant role under water scarcity conditions (Logar and Van den Berg, 2012)

Variable costs generated by externalities. The variation (positive or negative) of water costs due to factors not related to the consumers is an externality. For instance the desnitrificación cost of water polluted by fertilizers.

$O \& M$ costs. These include the personnel costs (fixed term) plus the variable costs linked to the production and distribution of water (energy, chemicals, etc.). Fixed term costs are sensitive to the quality standards of service.

Capital costs. They correspond to the annual amount that must be reserved to renew the infrastructures once their life period is finished.

Environmental costs. Currently, they include the taxes destined to minimize the impact on the environment derived from the abstraction of water (Kanakoudis et al., 2009). This is a cost defined by the environmental policies and the taxing of the resource itself (it is strictly a variable cost) and promotes efficiency.

Social Costs. They are intended to compensate for the inconveniences created to people who are alien to the activity (Coase, 1960). In the urban water cycle, they result in economic compensation for the problems created by public works in the network and, in some cases, can be higher than repair costs (Kanakoudis and Tolikas 2001).

Low water prices are typical in those services that only recover operation and maintenance costs, avoiding the recovery of the higher capital cost, regardless (IWA, 2010) of the way in which these costs are split (fixed or variables charges). This is common practice in countries from the 
Mediterranean basin. The inclusion of the capital costs represents the recovery of all economic costs, while a full cost recovery would also require the environmental and social costs to be recovered (Rogers et al., 1998). Lastly, it must be outlined that the different items included in the final consumer's bill are not enough to explain the wide spectrum of prices found in practice. Quality of service also plays a major role (den Blanken, 2009).

\section{COSTS STRUCTURE}

The proposed costs structure divides the required concepts into fixed and variable. This is the only way to determine the economic value of water losses. Fixed costs are linked to the utility's structure (they are also called structural costs), while those depending on the volume of produced water are called variable. This work assumes a variation of costs proportional to the produced volume, an option which is questionable since it does not take into account economies of scale. However, the assumption of a linear variation when associating the average cost of the produced volume to the marginal cost of water simplifies the problem (Wonnacott and Wonnacott, 1990).

This linearity can be applied to the three components of the marginal cost of water; namely the variable costs of the resource, energy costs and those derived from the shorter lifespan of facilities when there is leakage. In this respect, it is important to remember that infrastructures are assigned a certain useful life that enables the amortization of the assets to be determined. Depending on their operation and maintenance, their lifespan can be longer or shorter. Leaks increase the circulating flow rates in pipes, reducing their forecasted useful life, and therefore the amortization values. The need to replace a pipe earlier due to an excess in leakage represents a positive variable cost (not directly linked to production, but depending on leakage).

Taking all this into consideration, water costs can be arranged in a matrix (Table 1) that allows for a better understanding of a price bracket range that has already been shown by recent studies. In this matrix, rows represent the five concepts described above and the columns are the costs 
divided into their fixed and variable parts. The fixed costs are further divided into structural and those dependent on the useful life of the asset while the variable costs are shown according to dependence (resource, energy and increase in cost due to shorter useful life derived from leakage).

Table 1.- Water cost terms and their nature

\begin{tabular}{|c|c|c|c|c|c|}
\hline & \multicolumn{2}{|c|}{ FIXED } & \multicolumn{3}{|c|}{ VARIABLE, depending on volume: } \\
\hline & Structural & Variation of useful life & Resource & Energy & Useful life (leakage) \\
\hline $\begin{array}{l}\text { 1.- Availability of } \\
\text { the resource }\end{array}$ & - & - & $\begin{array}{l}\mathrm{C}_{13} \text { : Socio- } \\
\text { political }\end{array}$ & - & - \\
\hline $\begin{array}{l}\text { 2.- Operation and } \\
\text { maintenance }\end{array}$ & $\begin{array}{l}\mathrm{C}_{21} \text { :Technical } \\
\text { (depends on the } \\
\text { utility's structure) }\end{array}$ & - & $\begin{array}{l}\mathrm{C}_{23} \text { :Technical, } \\
\text { (there are variable } \\
\text { costs of collection, } \\
\text { potabilization and } \\
\text { distribution, } \\
\text { excluding energy } \\
\text { costs) }\end{array}$ & $\begin{array}{l}\mathrm{C}_{24} \text { : Technical } \\
\text { (there are energy } \\
\text { costs of collection, } \\
\text { potabilization and } \\
\text { distribution). } \\
\text { Complex metric. }\end{array}$ & - \\
\hline $\begin{array}{l}\text { 3.- Asset } \\
\text { amortization }\end{array}$ & $\begin{array}{l}\mathrm{C}_{31} \text { :Technical } \\
\text { (there are the initial } \\
\text { amortization of } \\
\text { assets) }\end{array}$ & $\begin{array}{l}\mathrm{C}_{32} \text { :Technical } \\
\text { (There is positive or } \\
\text { negative variation of } \\
\text { the amortization costs. } \\
\text { Depending on the state } \\
\text { of infrastructures, it } \\
\text { can influence the } \\
\text { forecasted useful life) }\end{array}$ & - & - & $\begin{array}{l}\mathrm{C}_{35} \text { :Technical } \\
\text { (There is variation of } \\
\text { amortization costs. } \\
\text { Always positive } \\
\text { because leaks reduce } \\
\text { useful life of } \\
\text { networks). }\end{array}$ \\
\hline $\begin{array}{l}\text { 4.- Environmental } \\
\text { cost }\end{array}$ & $\begin{array}{l}\mathrm{C}_{41} \text { : Technical } \\
\text { (when calculating } \\
\text { EIO-LCA*). } \\
\text { And Socio- } \\
\text { political } \\
\text { (In the economic } \\
\text { assessment of } \\
\text { impact). } \\
\text { Very complex } \\
\text { metric that is rarely } \\
\text { calculated. }\end{array}$ & $\begin{array}{l}\mathrm{C}_{42} \text { :Technical } \\
\text { (when calculating the } \\
\text { effect of variation of } \\
\text { useful life in EIO- } \\
\text { LCA*). }^{*} \text { And Socio-political, } \\
\text { (in the economic } \\
\text { assessment of impact). } \\
\text { Very complex metric } \\
\text { that is rarely calculated }\end{array}$ & $\begin{array}{l}\mathrm{C}_{43} \text { :Socio- } \\
\text { political }\end{array}$ & $\begin{array}{l}\mathrm{C}_{44} \text { :Technical } \\
\text { (when calculating } \\
\text { energy cost } \\
\text { consumption) } \\
\text { and Socio- } \\
\text { political, (when } \\
\text { related to } \\
\text { greenhouse gases } \\
\text { emitted). } \\
\text { Complex metric. }\end{array}$ & $\begin{array}{l}\mathrm{C}_{45} \text { : Technical } \\
\text { (when calculating the } \\
\text { reduction of the } \\
\text { useful life in EIO- } \\
\text { LCA }^{*} \text { ) } \\
\text { And socio-political } \\
\text { (economic variation } \\
\text { of the impact). } \\
\text { Very complex metric, } \\
\text { rarely calculated }\end{array}$ \\
\hline 5.- Social cost & \multicolumn{5}{|c|}{ Cs : Socio-economical and environmental (Very much depending on local regulations) } \\
\hline
\end{tabular}

Table 1 shows the 20 terms ( 8 of them null) that conform the cost structure. The table also shows the nature of the costs: technical if there is no doubt about its value, regardless of the complexity of the metric, and socio-political when the value depends on the importance assigned by society. Regarding the assessment period, fixed costs are annual while variable costs simply relate to the production unit $\left(\mathrm{m}^{3}\right)$. Finally, the singularity of social costs does not allow their integration in the matrix. They are neither fixed nor variable costs, as shown by their notation (a single sub-index).

Following are the definitions of the twenty matrix elements: 
On accounting balance sheets these costs are referred to as recurrent costs, and include:

- $\mathrm{C}_{11} \equiv 0$. Cost of the resource (is inherently variable).

- $\mathrm{C}_{21}$ : Cost of system operation and maintenance, regardless of water production, and primarily linked to staff.

- $\mathrm{C}_{31}$ : Annual cost of the depreciation of the infrastructures, calculated based on the initially estimated useful life.

- $\mathrm{C}_{41}$ : Fixed economic/environmental cost. Set based on the environmental impact of building the infrastructures.

Column 2: Fixed costs depending on the change in the forecasted useful life.

As previously mentioned, the annual depreciation of the infrastructures, $\mathrm{C}_{31}$, is calculated based on their initially forecasted useful life. If the actual useful life of the facility is extended, estimated annual depreciation will exceed actual depreciation, and if the actual useful life is shorter than expected, the opposite will occur. Therefore, maintenance which extends useful life reduces costs, whereas a lack of such maintenance will increase them.

Consequently, changes in capital and environmental costs linked to infrastructures are fixed and unrelated to water production. The variation (positive or negative) in the depreciation period (and then, $\mathrm{C}_{31}$ ), results in new capital and environmental costs (second column of Table 1).

- $\mathrm{C}_{12} \equiv 0$. A higher or lower useful life of the facilities does not modify the cost of the resource.

- $\mathrm{C}_{22} \equiv 0$. Operation and maintenance costs are included in $\mathrm{C}_{21}$.

- $\mathrm{C}_{32}$ : Variation (positive or negative) in the depreciation of infrastructures resulting from a change in the initially estimated period of useful life.

- $\mathrm{C}_{42}$ : Change in environmental cost resulting from a change in the period of useful life.

The variable costs included in the last three columns of the matrix in Table 1 are as follows: 
Column 3: Variable costs linked to the resource.

- $\mathrm{C}_{13}$ : Economic cost of the resource in its natural state (excluding environmental) prior to the stages of water supply and conveyance and water treatment at the urban water cycle.

- $\mathrm{C}_{23}$ : Variable cost of water production in different processes (such as potabilization), general disinfectants (such as chlorine) and reagents. This cost do not include the energy cost of production included in $\mathrm{C}_{24}$, which must necessarily be separated to assess the emissions of greenhouse gases associated with energy consumption.

- $\mathrm{C}_{33} \equiv 0$. A renewable resource cannot be depreciated.

- $\mathrm{C}_{43}$ : This is the environmental cost, or essentially the political cost of the resource. The cost contribution of citizens' environmental sensitivity is highly variable $\left(0.84 € / \mathrm{m}^{3}\right.$ in Denmark, - EPO, 2010-, and null in Spain).

Column 4: Variable costs linked to energy.

- $\mathrm{C}_{14} \equiv 0$. Resources in their natural state require no energy expenditure.

- $\mathrm{C}_{24}$ : Energy cost linked to the urban water cycle (including pumping, treatment and transport), which is proportional to the volume of water treated.

- $\mathrm{C}_{34} \equiv 0$. The depreciation of the infrastructure is not at all related to energy expenditure.

- $\mathrm{C}_{44}$ : The environmental cost of greenhouse gas emissions per cubic meter of water injected into the system.

Column 5: Variable costs relating to the shorter useful life of the facilities as a result of leakage.

The last column takes into account the shortening of the useful life of the facility due to leakage. These elements are as follows:

- $\mathrm{C}_{15} \equiv 0$. A higher or lower useful life of the facilities does not condition the cost of the resource. 
- $\mathrm{C}_{25} \equiv 0$. Operation and maintenance costs are fixed and included in $\mathrm{C}_{21}$.

- $\mathrm{C}_{35}$ : This is the increase in the annual depreciation of the infrastructure per volume unit resulting from a decreased period of useful life due to leakage.

- $\mathrm{C}_{45}$ : Environmental cost allocated to the greenhouse gas emissions per cubic meter of water leaked as a result of early rehabilitation.

Finally, it is appropriate to emphasize the interdependence of some of these costs. In this regard, since a more motivated, more qualified or simply more numerous staff will manage the system better (in this case, changes in staffing costs will influence the fixed operation and maintenance costs, $\mathrm{C}_{21}$ ), it can help reduce leakage and extend the useful life of the facilities, thereby conditioning other costs, namely $\mathrm{C}_{32}, \mathrm{C}_{24}, \mathrm{C}_{35}$ and $\mathrm{C}_{45}$. This dependence will undoubtedly alter the value of some elements of a given system, but it will not modify the structure of the proposed cost matrix in any way.

\section{CALCULATION OF WATER COSTS}

In a globalized world, the cost of equipment (pipes, valves or pumps) is almost independent from the location, while the installation manpower cost is not one of most significance. Even the variations around the globe of the much larger civil work costs cannot justify such differences in water prices. Only the cost of producing the resource can explain them to some extent. However, they cannot justify the extreme differences found in water prices. In fact, the cost of desalinated water can reach $1 \mathrm{US} \$ / \mathrm{m}^{3}$ (NRC, 2008) opposed to the cost of spring water, which is almost null.

Therefore, differences between Copenhague and Milán cannot be explained based on the price of the resource, considering that both cities use water from conventional sources. However, they can be explained by the matrix of prices, which is a faithful reflection of each country's water policy. Thus, the criteria to be used for specifying the elements included in the cost of tap water should be harmonised because a common methodology would allow for their comparison. 
Generally speaking, it should be easy to compare costs, because with the exception of some elements, costs are not difficult to calculate. Most elements, such as the depreciation of the infrastructures (regardless of whether or not the cost is passed on to the subscriber) are technical. Others, due to their social significance, depend on political decisions. A third group require the application of metrics of some complexity, a subject to which the authors of this study have devoted considerable attention (Cabrera et al., 2010). Only the fourth group of costs (linked to the environmental impact of construction) is difficult to estimate, although it is not currently accounted for. In conclusion, each element of the matrix (Table 1) is unique. Six are of a technical nature, two are of a social and political nature and the other six share both features. Additionally, the estimation of environmental costs (excluding those relating to the resource) require complex metrics.

It should be pointed out that intrinsec technical costs $\left(\mathrm{C}_{21}, \mathrm{C}_{31}, \mathrm{C}_{32}, \mathrm{C}_{23}, \mathrm{C}_{23}, \mathrm{C}_{24}\right.$ and $\left.\mathrm{C}_{35}\right)$ are closely related to technical training of the staff and to quality standards. Notable are those of the Netherlands, where the water supplied has low residual chlorine levels and there is loss of less than $5 \%$. The price paid by the user is relatively high (on average just over $1.5 € / \mathrm{m}^{3}$ ). However, the amount of bottled water consumed (liters per capita per year) is among the lowest in the world (den Blanken, 2009). Lastly, it should be pointed out that, given that major infrastructures are subsidized in some countries, certain technical costs are not amortised and therefore, in practice they become political costs which end up notably conditioning the final price of water.

\section{FINAL CONSIDERATIONS REGARDING THE PRICE OF TAP WATER}

The costs of leaks and apparent losses are not the same because the former finish their run through the urban water cycle in the distribution network while the apparent losses complete the whole cycle. For this purpose both types of losses should be separated by carrying out a water audit (Almandoz et al., 2005). The different elements of the equation can be determined as follows: 


$$
\forall=\forall_{r}+\forall_{u}=\forall_{r}+\left(\forall_{u l}+\forall_{u c}\right)
$$

Where $\forall$ is the volume injected into the system, $\forall_{r}$ is the amount registered by the meters, and $\forall_{u}$ is the uncontrolled volume (unlike the other two above), which is the same as the sum of the real losses $\forall_{u l}$ and the apparent $\operatorname{losses} \forall_{u c}$. All these volumes relate to the same period of time, which is generally one year.

It should be pointed out that while variable costs are based on the volume injected into the network $(\forall)$, in a universally metered system, their recovery is based on the volume registered by the users' meters $\left(\forall_{r}\right)$. To recover the water costs (from catchment to tap), subscribers must pay an average price $\bar{p}$ to compensate for all expenses. An adequate tariff structure should make such full cost recovery socially acceptable. Therefore, the sum of all costs, $\mathrm{C}_{\mathrm{T}}$ (fixed, $\mathrm{C}_{\mathrm{F}}$, plus variables, $\mathrm{C}_{\mathrm{V}}$ ) must be offset with the revenues from water tariffs billed. In other words:

$$
\bar{p} \forall_{r}=C_{F}+C_{V}=C_{F}+k \forall=C_{F}+k\left(\forall_{r}+\forall_{u}\right)
$$

This equation takes into account the proportionality between variable costs and water production, while ignoring social costs due to their lack of weight in the global economic balance, and also due to the fact that they are often indirectly included in operation and maintenance costs (in order to cover damage to third parties, companies takes out insurance policies).

The combination of equations (1) and (2), which is equation (3), show the average price that should be paid by subscribers.

$$
\bar{p}=\frac{C_{F}}{\forall_{r}}+k \frac{\forall}{\forall_{r}}=\frac{C_{F}}{\forall_{r}}+k\left(1+\frac{\forall_{u}}{\forall_{r}}\right)
$$

This leads to equation (4), which is equal to the excess cost resulting from water losses in the system evidencing that inefficiency is never free, regardless of whether or not it is is recovered through billing. 


$$
\Delta \bar{p}=k \frac{\forall_{u}}{\forall_{r}}
$$

Where the total annual expense due to losses is:

$$
\Delta \bar{p} \forall_{r}=k \forall_{u}
$$

When all the water measured is billed, the increase in the average price is proportional to the ratio between losses and the volume of water recorded. With payment-free subscribers, the global economic balance will be established by deducting the unbilled volumes from the total amount registered appearing in equation (2) and successive $\forall_{r^{\prime}}$, which is equal to the difference between the total registered and the unbilled volumes measured.

The above calculations relate to the average price of tap water. A similar analysis on the second part of the cycle (wastewater collection, treatment and discharge) would allow the price payable for sanitation to be determined. In any case, since only the volume of drinking water is measured, the average price of the second part of the cycle will also refer to $\forall_{r}$. Consequently, both apparent and real losses increase the average price of tap water. However, while leaks are an absolute loss in relation to which the additional cost is paid by customers, apparent losses benefit some customers since they only pay for the water measured. The additional cost, which is also allocated over the registered volume, is greater because the apparent losses also run through the second half of the urban water cycle. The relationship between the variable costs of each semi-cycle will depend on the system. It is generally between 0.5 and 2.5 , which means that the cost of apparent losses is from $150 \%$ to $300 \%$ higher than real losses. This is a cost relationship that can be easily determined when, as in Berlin, all costs are recovered. With a variable tap water fee of $2.027 € / \mathrm{m}^{3}$ and a variable water treatment fee of $2.464 € / \mathrm{m}^{3}$ (with an additional rain water drainage fee of $1.897 € / \mathrm{m}^{2}$ and year), the relationship between variable costs of each semi cycle is 1.192 (http://www.bwb.de). Therefore, apparent loss costs will be $219.2 \%$ higher than real cost losses. 


\section{FOUNDATIONS OF THE ECONOMIC ASSESSMENT OF LEAKS}

To better clarify the concepts discussed, following is a case study on the economic value of leaks. As they only depend on variable costs, there is no need to calculate fixed costs, reducing the problem to the calculation of the seven variables of the price matrix (Table 1). The three linked to the resource $\left(\mathrm{C}_{13}, \mathrm{C}_{23}\right.$ and $\left.\mathrm{C}_{43}\right)$ are known. The fourth, $\mathrm{C}_{45}$, which relates to complex metrics, is not taken into consideration in this analysis. This is an element which is not usually included in the price of water. As previously mentioned, authors have devoted a great deal of attention to the three remaining variables $\left(\mathrm{C}_{24}, \mathrm{C}_{44}\right.$ and $\left.\mathrm{C}_{35}\right)$ in recent years. Particularily, the calculation of $\mathrm{C}_{24}$ and $\mathrm{C}_{44}$ are explained in previous studies (Cabrera et al., 2010). $\mathrm{C}_{35}$, the additonal cost of anual depreciation is explained as follows:

Depreciation is the process by which assets lose value over the course of their useful life. To distribute the cost of the initial investment into costs which can be included on annual balance sheets, the depreciation factor $a$, or annual cost payable during the useful life of the element under consideration $T$, is used. Depreciation can be reduced in the event of a significant volume of losses. Leakage does not only condition the useful life of pipes. It can also lead to the need to anticipate the expansion of the water treatment systems. In any case, it is recognised that the amount by which the useful life of all these elements is shortened is similar to the amount by which the useful life of the network pipes is decreased. Additionally, most of the investment required by the first half of the urban water cycle relates to the distribution network, a percentage represented by $\xi$, the ratio between the investment in the network and the system (from catchment to the user's tap). Therefore the total investment to be depreciated $\mathrm{I}_{\mathrm{T}}$ is calculated as follows:

$$
\mathrm{I}_{\mathrm{T}}=\frac{C_{p} \cdot L_{n}}{\xi}
$$

Where $C_{p}$ is the average cost of a pipe per linear meter, $L_{n}$ the total length of the network, and $\xi$ the ratio between the assets of the distribution network and of the whole of the system. The 
parameter $\xi$ moves within a range and is determined by means of an asset analysis of the infrastructures. Based on the performance of real assets in Spain it can be concluded that it can reach 0.80 (system with a convencional source), with a minimum value of 0.50 (water from a desalination plant, whose cost is always relevant).

Under these assumptions, the difference between the depreciation factor of a system without losses $\left(\mathrm{a}_{\mathrm{i}}\right)$ and one with losses $(\mathrm{a})$, is calculated by decreasing the useful life of the facilities $\left(T_{i}\right.$ in the initial case, with a low level of leakage, and $T$ in the real case). In both cases, the deflated discount rate $r$ (which includes the real interest rate and the inflation rate) is identical. The respective depreciation factors are:

$$
a=\frac{r(1+r)^{T}}{(1+r)^{T}-1} \quad y \quad a_{i}=\frac{r(1+r)^{T_{i}}}{(1+r)^{T_{i}-1}}
$$

The nominal annual depreciation $\mathrm{C}_{31}$ is obtained by multiplying the depreciation factor by the investment $\mathrm{I}_{\mathrm{T}}$, while $\mathrm{C}_{32}$ should be calculated taking into account the real period of useful life. Being both fiexd costs, no one of them affects the final value of the water losses. The important one is the additional annual cost due to leakage, $\mathrm{C}_{35}$, that can be calculated as follows:

$$
\mathrm{C}_{35}=\left(\mathrm{a}-\mathrm{a}_{\mathrm{i}}\right) \mathrm{I}_{\mathrm{T}}
$$

\section{CASE STUDY}

The case study presented is based on a previously analysed synthetic network (Figure 1 and Table 2) (Cabrera et al., 2010). A significant level of real losses is assumed $\left(1.51 \mathrm{~m}^{3} / \mathrm{h} / \mathrm{km}\right.$, yielding a global efficiency of $69.65 \%$ ), a typical value in practice. In this example, apparent losses are not considered. Two different cases are considered. In the first one (case I) the water comes from an aquifier which is $75 \mathrm{~m}$ deep (the related energy cost for lifting is $0.296 \mathrm{kWh} / \mathrm{m}^{3}$ ). In the second one (case II) the water is desalinated (unit energy expense, -NRC, 2008-, $3.65 \mathrm{kWh} / \mathrm{m}^{3}$ ). The environmental cost of groundwater considered is, as in Denmark, very high $\left(\mathrm{C}_{43}=0.84 € / \mathrm{m}^{3}\right)$. If the 
water is desalinated (Case II), its value is usually null, although there is a real environmental impact due to the higher alkalinity of the water returned to the sea.

The economic expense of leakage to be borne by the company will depend on its economic system. There are three possibilities:

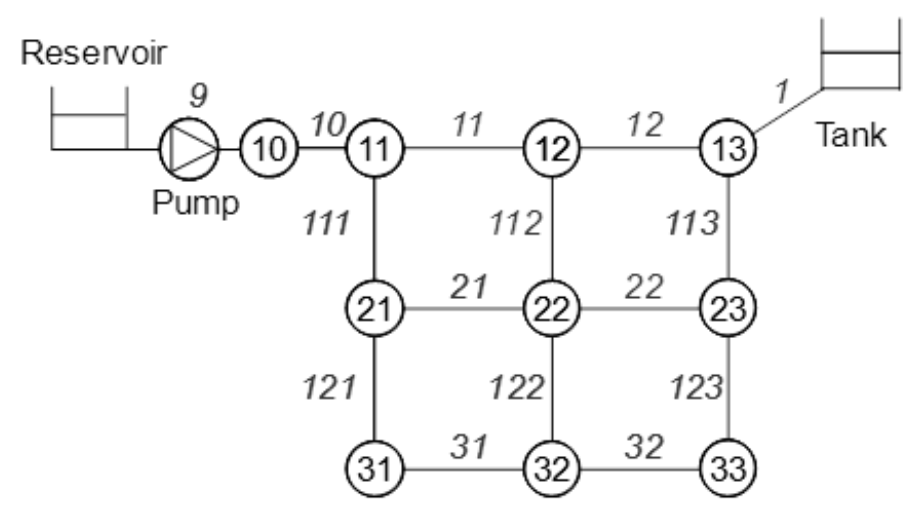

Figure 1. Outline of the Case Study

- Subsidized scenario. Just the costs of the resource and the operation and maintenance costs are passed on to the customer (Full supply cost).

- Non-subsidized scenario. Depreciation costs are added to the above (Full economic cost).

- Scenario where all costs are covered, including environmental ones (Full cost).

Table 2. Basic features of the network

\begin{tabular}{|c|c|c|c|c|c|c|}
\hline Line & $\begin{array}{c}\text { Length } \\
(\mathbf{k m})\end{array}$ & $\begin{array}{c}\begin{array}{c}\text { Diameter } \\
(\mathbf{m m})\end{array} \\
\end{array}$ & Node & $\begin{array}{c}\text { Base demand } \\
(1 / \mathrm{s})\end{array}$ & $\begin{array}{l}\text { Elevation } \\
(\mathbf{m})\end{array}$ & $\begin{array}{c}\begin{array}{c}\text { Emitter coefficient } \\
\left(\mathbf{m}^{3-\alpha} / \mathbf{s}\right)\end{array} \\
\end{array}$ \\
\hline 10 & 2 & 400 & Node 10 & 0 & 5.8 & 0.0026 \\
\hline 11 & 2 & 300 & Node 11 & 5 & 5.8 & 0.0104 \\
\hline 12 & 2 & 350 & Node 12 & 5 & 4 & 0.0104 \\
\hline 21 & 2 & 200 & Node 13 & 3 & 2 & 0.0104 \\
\hline 22 & 2 & 200 & Node 21 & 5 & 4 & 0.0131 \\
\hline 31 & 2 & 200 & Node 22 & 6.5 & 2 & 0.0157 \\
\hline 111 & 4 & 200 & Node 23 & 5 & 0 & 0.0131 \\
\hline 112 & 4 & 250 & Node 31 & 3 & 4 & 0.0078 \\
\hline 113 & 4 & 300 & Node 32 & 3 & 5 & 0.0104 \\
\hline 121 & 4 & 200 & Node 33 & 3 & 0 & 0.0078 \\
\hline 122 & 4 & 200 & Reservoir & - & 25 & - \\
\hline 123 & 4 & 200 & Tank & - & 32 & - \\
\hline 32 & 2 & 200 & & & & \\
\hline 1 & 2 & 400 & & & & \\
\hline
\end{tabular}




\section{Complementary problema data}

The variable cost matrix data (columns 3,4 and 5) in each of the six scenarios studied (two relating to water and three to cost recovery), is as follows:

- Variable cost of the resource $\mathrm{C}_{13}=0.10 € / \mathrm{m}^{3}$, for payment to the owner of the well (case I) while in case II, $\mathrm{C}_{13}=0 € / \mathrm{m}^{3}$ (sea water, without cost).

- Variable cost of resource operation and maintenance, $\mathrm{C}_{23}=0.03 € / \mathrm{m}^{3}$ (case $\mathrm{I}$, discrete value as it relates to water) and $\mathrm{C}_{23}=0.068 € / \mathrm{m}^{3}$ (for case II).

- Variable energy cost $C_{23}$. Assessed using the average cost of the energy in Spain, $C_{e}=0.10$ $€ / \mathrm{kWh}$, and based on water and energy audits.

- Investment $\mathrm{I}_{\mathrm{T}}=20.8 \mathrm{M} €$ (case I) e $\mathrm{I}_{\mathrm{T}}=27.2 \mathrm{M} €$ (case II). Determined assuming an average cost per linear metre of $\mathrm{C}_{\mathrm{p}}=400 € / \mathrm{m}$, and a factor $\xi=0.77$ (system without extensive construction work, case I) and $\xi=0.59$ (case II).

- Deflated discount rate $\mathrm{r}=3 \%$.

- Assumed depreciation period, $\mathrm{T}=30$ years (network with leaks) and $\mathrm{T}_{\mathrm{i}}=50$ (network without leaks).

- $\mathrm{g} \mathrm{CO}_{2} / \mathrm{kWh}$ relationship, 0.554. Is the corresponding to the Spanish mix (Table 3)

- Environmental cost of emissions, $12.36 € /$ tons of $\mathrm{CO}_{2}$ based on the ECE (European Climate Exchange).

Table 3.- Spanish energy mix

\begin{tabular}{lllllll}
\hline & Natural Gas & Oil Fired & Coal Fired & Nuclear & Hydraulic & Others \\
\hline Energy source & $29.8 \%$ & $7.9 \%$ & $22.4 \%$ & $19.8 \%$ & $9.7 \%$ & $10.4 \%$ \\
\hline Emissions $\mathbf{g ~ C O} / \mathbf{k W h}$ & 554 & 865 & 1432 & 0.0 & 0.0 & 0.0 \\
\hline
\end{tabular}

\section{Results of water and energy audits}

The results for the audited system are as follows:

- Injected water: $\forall_{N}\left(t_{p}\right)=1.746 \mathrm{Hm}^{3} /$ year. 
- Delivered water: $\forall_{\mathrm{U}}\left(\mathrm{t}_{\mathrm{p}}\right)=1.214 \mathrm{Hm}^{3} /$ year.

- Real losses: $\forall_{\mathrm{L}}\left(\mathrm{t}_{\mathrm{p}}\right)=0.529 \mathrm{Hm}^{3} /$ year.

- Annual variation of the energy in the volumen stored in a tank: $\Delta \forall_{\mathrm{C}}\left(\mathrm{t}_{\mathrm{p}}\right)=0.003 \mathrm{Hm}^{3} / \mathrm{year}$ (a neglibible amount, less than $0.2 \%$, as compared to the volumen injected into the system) Energy audits (in MWh/year) on real and ideal networks (without leaks), provide data on the annual amount of energy input into the network (natural $E_{n}\left(t_{p}\right)$ and pumped $E_{p}\left(t_{p}\right)$ ), the output (delivered to users $\mathrm{E}_{\mathrm{u}}\left(\mathrm{t}_{\mathrm{p}}\right)$, losses in leaks $\mathrm{E}_{\mathrm{l}}\left(\mathrm{t}_{\mathrm{p}}\right)$, dissipated in friction $\mathrm{E}_{\mathrm{f}}\left(\mathrm{t}_{\mathrm{p}}\right)$ ) as well as the variation in energy stored in tailings $\Delta \mathrm{E}_{\mathrm{c}}\left(\mathrm{t}_{\mathrm{p}}\right)($ Cabrera et al., 2010). In this case the results are:

Table 4.- Annual energy audits (in MWh/year). Network with and without leaks.

\begin{tabular}{ccc}
\hline & Leaky network & Non-leaky network \\
\hline$E_{N}\left(t_{p}\right)$ & 118.98 & 82.72 \\
$E_{P}\left(t_{p}\right)$ & 295.68 & 215.50 \\
$E_{U}\left(t_{p}\right)$ & 168.76 & 179.68 \\
$E_{l}\left(t_{p}\right)$ & 77.73 & 0 \\
$E_{f}\left(t_{p}\right)$ & 167.56 & 118.52 \\
$\Delta E_{c}\left(t_{p}\right)$ & 0.19 & 0.21 \\
\hline
\end{tabular}

\section{Unit costs of leaked water (Case I)}

The variable costs for Case I and Case II are detailed below. The data is as follows:

- $\mathrm{C}_{13}=0.10 € / \mathrm{m}^{3}$ (data problem).

- $\mathrm{C}_{23}=0.03 € / \mathrm{m}^{3}$ (data problem).

- $\mathrm{C}_{24}=0.045 € / \mathrm{m}^{3}$, ratio between the network energy difference (with and without leaks) and the volumen leaked, plus the energy consumed in the way between the catchment of the resource and its input in the network.

- $\mathrm{C}_{35}=\frac{a-a^{\prime}}{\forall_{f}} I_{T}=\frac{0.051-0.039}{1530.3} 20.810^{6}=0.461 € / \mathrm{m}^{3}$, calculated based on depreciation factors $\mathrm{a}=0.051$ and $\mathrm{a}_{\mathrm{i}}=0.039$.

- $\mathrm{C}_{43}=0.84 € / \mathrm{m}^{3}$

- $\mathrm{C}_{44}=0.003 € / \mathrm{m}^{3}$. Obtained from energy and emisión costs. 
Variable costs detailed on Table 5 summarises the results (right, case I, left, case II).

\section{Economic value of leaks}

In both cases, the value of leaks will depend on the scenarios considered.

1. Full supply cost. In the case of the most typical subsidy, the economic value of the leaks depends on the variable costs of the two first rows.

2. Full economic cost. The variable costs from the third row must be added to the above.

3. Full cost recovery. It includes all variable costs (four rows).

Table 5.- Cost matrix for the costs analysed.

\begin{tabular}{|c|c|c|c|c|c|}
\hline & \multicolumn{2}{|c|}{ FIXED } & \multicolumn{3}{|c|}{ VARIABLE, depending on volume: } \\
\hline & Structural & Variation of useful life & Resource & Energy & $\begin{array}{l}\text { Useful life } \\
\text { (leakage) }\end{array}$ \\
\hline Availability of the resource & - & - & $0 \quad 0.030$ & - & - \\
\hline Operation and maintenance & $\mathrm{C}_{21}$ & - & $\begin{array}{lll}0.068 & 0.030\end{array}$ & $\begin{array}{lll} & 0.368 & 0.034\end{array}$ & - \\
\hline Asset amortization & $\mathrm{C}_{31}$ & $\mathrm{C}_{32}$ & - & - & $0.602 \quad 0.461$ \\
\hline Environmental cost & $\mathrm{C}_{41}$ & $\mathrm{C}_{42}$ & $0 \quad 0.840$ & $0.010 \quad 0.001$ & $\mathrm{C}_{45}$ \\
\hline Social cost & \multicolumn{5}{|c|}{$\mathrm{C}_{5}$} \\
\hline
\end{tabular}

Table 6 summarises the results of this analysis for the six different scenarios. The first two rows show the unit cost of the leaks $\left(€ / \mathrm{m}^{3}\right)$. The sum for each box is obtained by adding together the variable costs. The following rows show the annual additional cost resulting from leaks (€/year), which is obtained multiplying the unit costs by the leaked volume $\left(529000 \mathrm{~m}^{3} / \mathrm{year}\right)$. The last three rows represent the increase in the average price of water to be paid by subscribers to recover costs, which is calculated using equation (5).

Table 6.- Unit costs of leaked water $\left(€ / \mathrm{m}^{3}\right)$, annual additional costs resulting from leaks $(€ /$ year) and increase in the average cost of water caused by leaks $\left(€ / \mathrm{m}^{3}\right)$

\begin{tabular}{lccc}
\hline Costs $\left(\boldsymbol{\epsilon} / \mathbf{m}^{\mathbf{3}}\right)$ & Full supply cost & Full Economic cost & Full cost recovery \\
\hline Case I & 0.175 & 0.636 & 1.479 \\
Case II & 0.448 & 1.050 & 1.076 \\
\hline Costs $(\boldsymbol{€} /$ year) & Full supply cost & Full Economic cost & Full cost recovery \\
\hline Case I & 92575 & 336444 & 782391 \\
Case II & 236992 & 555450 & 569204 \\
\hline$\Delta \mathbf{p}\left(\boldsymbol{\epsilon} / \mathbf{m}^{\mathbf{3}}\right)$ & Full supply cost & Full Economic cost & Full cost recovery \\
\hline Case I & 0.076 & 0.277 & 0.644 \\
\hline Case II & 0.195 & 0.457 & 0.469 \\
\hline
\end{tabular}


The results of Table 6 show that in case I the leakage level would be aceptable given annual losses amounting to $92575 €(254 € /$ day). But in no case would annual losses amounting to $782391 €$ (2143 €/day ) be acceptable, evidencing that cost recovery leads to efficiency. In any case, it should be emphasized that the procedure followed is much more important than the hypothesis that lead to the numerical values used (Tables 5 and 6). In fact, the combination of unit values of variable costs leads to situations which might in some way be contradictory (in practice a high level of real losses mismatched with a high environmental cost).

\section{Final remarks}

This example is simply a simulation of a theoretical case based on unit values that are possible in practice, although certain combinations may be unlikely. Rather than exploring a specific case which might occur in reality, the aim was to show the high economic cost of leaks in cases where all costs are recovered. This paper also shows how to calculate the average price of tap water for each case (equation 3), a price that indeed depends very much on the costs finally recovered.

With respect to variable costs, which are analysed more extensively in the case study, it is important to point out that:

- In the current energy crisis, this cost is relevant. In this example, the value relating to leaks ranges from 0.045 to $0.380 € / \mathrm{m}^{3}$, figures which do not include the whole of the urban cycle, because the sum of the energy only takes into account the distribution stage. Still lacking is the second part of the cycle, which includes, inter alia, the energy expense of wastewater treatment.

- Excluding the environmental cost, the variable costs of case I are lower than in case II because the groundwater energetically requires a much lower expense than desalinated 
water, and also requires less of an investment. Therefore, and unless all costs are recovered in case I, the economic value of the leakage is lower.

- The inclusion of significant environmental costs tilts the balance towards desalinated water (Case II). However, there is a difference. In case I environmental tax is collected by the government and is allocated to the improvement of the natural environment. In case II, the funds are lost.

- The environmental cost calculated on the basis of greenhouse gas emissions taking into account current market prices has a symbolic cost $(0.026-0.003 €)$, even if the water comes from a desalination plant.

- Indeed, Green House Gas emissions policies are very complex. It should be taken into account that while the water environmental cost results in a local benefit (protecting the aquifer and consequently, the owner), emissions are globalised.

- In subsidized systems, earlier than planned investments due to poor management (high numbers of leaks) are a hidden cost. Even though the results obtained $\left(0.461 € / \mathrm{m}^{3}\right.$ and $0.602 € / \mathrm{m}^{3}$ ) are only theoretical, it is evident that they may be of relevance.

- When costs are recovered, the user pays economic losses intrinsic to leaks without benefitting the company. If the price is not increased, costs are only partially recovered and the system is not economically sustainable.

- If a significant portion of the volume is identified as apparent losses, the related intrinsic costs are apportioned among all users. This will benefit users whose real consumption exceeds the volume registered by their meter. Additionally, apparent losses also contribute to an increase in expenses in the second part of the cycle. Therefore, from a global economic perspective, they are worse than real losses. 


\section{CONCLUSION}

This paper first explores why the price of tap water is so variable throughout the world.

Differences of such significance cannot be linked to local factors, technological issues or the country's per capita income. To understand the reason for these differences, it is necessary to study the cost structure of each water distribution system. A detailed analysis evidences that many costs are of a social - political nature and are linked to the country's water culture. On the other hand, the technical elements depend on two factors, the quality standards met by the services provided and the fulfilment of the cost recovery principle. Major infrastructure projects that are subsidized and therefore not included in the cost matrix, give rise to water pricing policies that are not in line with reality.

The second part of the paper focuses on variable costs that enable the economic value of the water losses to be calculated. Finally, it should be emphasized that the matrix cost structure designed allows the consequences of specific political actions to be easily valued. A sensitivity analysis using this cost structure can be immediately performed. Therefore, it is important for metrics to be available which enable all costs to be determined, whether they are fixed or variable.

\section{REFERENCES}

Almandoz J, Cabrera E, Arregui F, Cabrera Jr E, Cobacho R (2005) Leakage assessment through water networks simulation. J. of Water Resources Planning and Management. ASCE. Nov-Dic. 2005 pp 458-466

BDEW (German Association of Energy and Water Industries) (2010) Comparison of European Water and Wastewater Prices German Association of Energy and Water Industries, Bonn

Cabrera E, Pardo M.A, Cobacho R, Arregui F.J., Cabrera Jr E (2010) Energy Audit of Water Networks J. of Water Resources Planning and Management. ASCE. Nov-Dic. 2010 pp 669-677

Coase RH (1960) The Problem of Social Cost Journal of Law and Economics, October 1960

den Blanken M (2009) Asset Management. A necessary tool for a modern water company AWWA International Conference on Strategic Asset Management. Miami 11 - 13 November 2009 
EPO (Eurostat Press Office) (2010) Facts and figures on the environment: from environmental taxes to water resources Eurostat Press Office. Luxembourg, December 2010.

EU (European Union) (2000) Directive 2000/60/EC of the European Parliament and of the Council of 23 October 2000 Official Journal of the European Communities. 22.12.2000. Pp L $327 / 1$ to L $327 / 72$

IWA (International Water Association) (2010) International statistics for water services. Montreal 2010. Canada. International Water Association. London.

Kanakoudis V, Tsitsifli S (2009) Water Pricing Policies in Greece: is there a Common Understanding?. $2^{\text {nd }}$ International conference on water economics, statistics, and finance Alexandroupolis, Thrace, Greece, 3-5 July 2009.

Kanakoudis V, Gonelas K, Tolikas D (2011) Basic principles for urban water value assessment and price setting towards its full cost recovery - pinpointing the role of the water losses. Journal of Water Supply: Research and Technology. Vol 60 No 1 pp 27-39.

Kanakoudis V, Tolikas D. (2001) The role of leaks and breaks in water networks: technical and economical solutions J Water SRT - Aqua 50 (2001) 301-311

Logar I, Van den Berg J (2012) Methods to assess costs of drought damages and policies for drought mitigation and adaptation: Review and recommendations. Water Resources

Management. DOI 10.1007/s11269-012-0119-9

Molinos-Senante M, Hernández-Sancho F, Sala-Garrido R (2012) Tariffs and cost recovery in water reuse. Water Resources Management. DOI 10.1007/s11269-012-0111-4

NRC (National Research Council) (2008) Desalination a national perspective. NAP Press, Washington, D.C. National Research Council. Ottawa, Canada.

OECD (Organisation for Economic Co-operation and Development) (2010) Pricing Water Resources and Water and Sanitation Services. OECD. Paris.

OFWAT (Office of Water Services) (2009) Future water and sewerage charges 2010-15: Final determinations. OFWAT (Office of Water Services) Birmingham UK

Rogers P, Bhatia R, Huber A (1998) Water as a social and economic good: How to put the principle into practice. Global Water Partnership, Swedish International Development Cooperation Agency.

Roth A (2001) Water Pricing in the EU. A Review. European Environmental Bureau (EEB). Brussels

Wonnacott P, Wonnacott R (1990) Economics. $4^{\text {th }}$ edition. John Wiley, 1990

Zhu X, van Ierland EC (2012) Economic modeling for water quantity and quality management: a welfare program approach Water Resources Management. DOI 10.1007/s11269-012-0029-X 
I hereby certify that I have revised the translation of this document from Spanish to English and have not encountered any errors or incorrectly used terminology.

Katherine Matles

English/Spanish Translator

kmatles@akmtranslations.com 